\title{
Universal Access in Historic Environment and Accessibility of The Haci Hasan Mosque in Eskisehir osman Tutal
}

\section{Abstract}

Urban heritage is one of the primary sign and symbols of human evolution through history. It means inherited civilization of predecessors and it is a unique and irreplaceable resource which reflects a rich and diverse expression of past societies and forms an integral part of cultural identity. It is not limited to the language or literature alone, but in the same time it reflects the capacity of man to overcome surrounding environment. It also includes the physical and sentimental elements of the community together with philosophy, religion, science, art and architecture in a society. In this context urban heritage, especially historic buildings and places, are significant because of their uses as places where people's daily life activities. However, many heritage buildings also offer specific challenges that need to be overcome when providing access for all. Therefore especially for people with disabilities, elderly people or other types of temporary impairments, barriers exist which make visiting and using historic buildings and places difficult or sometimes impossible. For a society based on freedom and equal rights, making the built heritage more accessible is a key to providing its citizens with autonomy, freedom of choice and the means to pursue an active social and economic life. Accessibility is therefore fundamental
Keywords: Mosque accessibility, universal design, historic environment, Eskisehir

Assoc. Prof. Dr. Architectural Department, Architecture and Design Faculty, Anadolu University, Eskisehir, Turkey Email: otutal@anadolu.edu.tr Orcid ID: http://orcid.org/0000-0003-14545514 
right to access to the other rights and to fully participate in to the daily life.

This study, which focuses on the accessibility of historic environment, is to discuss what actions are essential to ensure access and equal mobility conditions within mosque architecture to all people, regardless the diversity of their (dis)abilities.

\section{INTRODUCTION}

One of the key requirements for a sustainable society is that everyone should be able to participate in and enjoy the social, economic and cultural assets of that society. Therefore, sustainable and inclusive society recognizes that everyone should be able to enjoy easy and inclusive access the historic environment. Improving the universal access and removing the barriers to access in historic environment can allow more people to visit and use the historic environment. Providing accessibility of the built environment, especially historical buildings, will also increase the awareness and cultural, social and economic value. Moreover, it is also essential to be aware of people's different needs and how these needs can be met in a variety of ways. Although well-planned access strategies, developed at an early stage, can avoid excessive intervention and cost, making historic buildings accessible can be more difficult than making non historic buildings accessible. For this reason, for successfully improving access to historic buildings and places, it is necessary to address both conservation and accessibility needs in an integrated and balanced manner (Güler \& Tutal, 2017). It is important to remember that often the best and most appropriate way to make historic places more accessible is through management solutions which may sometimes require little physical intervention or alteration of historic fabric.

\section{HISTORIC ENVIRONMENT AND UNIVERSAL DESIGN}

All aspects of the environment resulting from the interaction between people and places through time like cultural heritage, protected areas, historic buildings and monuments, monumental buildings and other archaeological areas are all heritage assets. They are an integral part of our cultural identity and contribute towards a strong sense of place, whether in a local, regional or national context. The historic environment including heritage assets is the physical evidence of past human activity and it is a rich and diverse part of countries' urban heritage. It brings together people with their past life, place, and with traditions, stories and memories linked to those places. It also gives some messages to the future from past. So, it takes in all aspects of the 
environment as a whole that have been shaped through human activity.

Although conservation responsibilities and building codes have special allowances for making changes to existing buildings, for historic environment (buildings and places) the best and most appropriate way to protect them is to keep them in active use. The survival of most historic environments depends upon their continued and viable use, among other interventions and they require adaptations and alterations to improve access. For this reason, the survival of most historic buildings depends upon their continued, viable use. They are irreplaceable, but sometimes they need to be functional or structural changed or regenerated (Sawyer, 2015). Changes to improve access may well contribute to a building's continued viability. Well-planned/designed alterations and access strategies, developed at an early stage, can avoid excessive intervention and cost. Nonetheless where intervention is inevitable, best appropriate designed solutions should be prepared. Furthermore, it can be possible to provide access for all without compromising a building's special interest with careful planning and designing.

For people with disabilities, barrier exist which make visiting and using historic environment difficult or commonly impossible. It is essential to be aware of people's different needs and how these needs can be met in a variety of ways for making the built heritage more accessible, usable and visitable. In terms of accessibility, it is not always necessary to remove an obstacle. In many cases the accessibility can be provided by reasonable adjustment, little physical intervention or adaptations and alterations of historic fabric. Sometimes, the same desired result can also be achieved by rearranging the use of the space without the need for wide physical adaptations.

Among the little physical intervention or adaptations, particularly reasonable adaptation is an important step for countries that do not have inclusive or universal design practice. "Reasonable adaptation" means necessary and appropriate modification and adjustments not imposing a disproportionate or undue burden, where needed in a particular case, to ensure to persons with disabilities enjoyment or exercise on an equal basis with others of all human rights and fundamental freedoms (URL-1).

It is very important that some simple questions such as;

-what is a reasonable adaptation?

-what are the statutory obligations that have to be met in terms of accessibility and conservation principles?

-who is going to be responsible for reasonable adaptation? 
-how much will adaptation cost and how long is adjustment going to take?

are answered for the access strategy of any planning and designing (Sawyer, 2015). With well-planned/designed access strategy together answers of the questions above should be possible to provide accessibility for people with disabilities. In this planning/designing process every effort should be made to minimise loss of, or damage to, the qualities of the built environment.

Everyone has an equal right to participate fully in daily life and places where this life passes, to the maximum extent possible. Especially people with various disabilities are to have the same opportunity to participate as others. This has been made clear through the Convention on The Rights of Persons with Disabilities which entered into force in October 2009. The purpose of the present Convention is to promote, protect and ensure the full and equal enjoyment of all human rights and fundamental freedoms by all persons with disabilities, and to promote respect for their inherent dignity (URL-1).

Although there are some professionals write about Universal Designing (Steinfeld \& Tauke, 2002), or Design for More (Herssens, 2013) to express the unceasing endeavour, today Universal Design (UD) is an important strategy for creating a society where everyone can take part in an equal manner. Therefore UD is a non-exclusive design concept. Everyone is affected by universal design and universal design affects everyone. It was first used and promoted in the United States by Mace in 1985 to communicate a design approach that could be utilized by a wider range of users. (Mace, 1985; Preiser \& Ostroff, 2001). Universal design is defined by the late Ron Mace as follows: "The design of products and environments to be usable by all people, to the greatest extent possible, without the need for adaptation or specialized design" (Mace, 2013). Among the international community, there are multiple names for and definitions of universal design. Some are broader, others are narrower, but the basic idea is the same; it is about rights and the avoidance of exclusion (Manley, 2011). Regardless of wording, the goal is profound: buildings and places have to be accessible and usable as possible for as diverse a user population as possible.

As a design concept, UD has a greater effect on specific groups of people who are concerned about the design of the built environment. For instance, wheelchair users, pregnant women, caregivers of the elderly, people with various functional limitations, people with babies in strollers, and bicycle riders are 
concerned about curb cuts or sloping curbs. This synergy of diverse groups makes the design universal (All, 2008). UD for majority-world countries can then be defined as a concept that not only extends beyond issues of accessibility of the built environment, but also covers the social, cultural, and economic issues, which are major influences in uniting normal people and people with different physical, mental, or psychological abilities. UD should be accepted as an approach that values and celebrates human diversity (Balaram, 2001).

The aim of universal design is to develop theory, principles and solutions to enable everybody to use the same physical solutions to the greatest extent possible. It is helpful to educate planners, architects, designers, builders and citizens about the purpose and benefits of universal design for the whole community so that they understand its value and work to find good solutions to problems (All, 2008). Therefore, universal design opposes, ideologically and politically, all unnecessary and stigmatizing specialized solutions, whether they are intended for people with disabilities or other groups of the population. Equal status, equal treatment and equal merit are key concepts. The intent of the universal design concept is to simplify life for everyone by making products, communications, and the built environment more usable by more people at little or no extra cost. The universal design concept targets all people of all ages, sizes and abilities (Aslaksen, Bergh, Bringa, \& Heggem, 1997).

UD is not a standard, either national or international, but it may include design factors which might ordinarily adhere to national or international standards. UD may or may not include standards, but the design must be universally acceptable and usable by the population that will use the specific piece of the built environment. UD does not have hard and fast rules. It is whatever the designer intends for it to be, but it must follow some general principles (All, 2008)

A set of universal design guidelines was developed by the Centre for Universal Design, North Carolina State University with a group of experts (architects, product designers, engineers, and environmental design researchers). The resulting Principles of Universal Design were as follows (URL-2):

Principle 1: Equitable Use

Principle 2: Flexibility in Use

Principle 3: Simple and Intuitive Use

Principle 4: Perceptible Information

Principle 5: Tolerance for Error

Principle 6: Low Physical Effort 
Principle 7: Size and Space for Approach and Use

Each of these principles should be applied in making decisions about how to make historic buildings accessible to all persons, regardless of disability. These principles was also defined and then expanded in a set of guidelines. The purpose of the Principles of UD and their associated guidelines was to articulate the concept of universal design in a comprehensive way. The principles reflected the authors' belief that basic universal design principles applied to all design disciplines, including those that focused on built environments, products, and communications. Therefore, the principles are intended to guide the design process, allow systematic evaluation of designs, and assist in educating both designers and consumers about the characteristics of more usable design solutions (Story, 2001)

\section{ACCESSIBILITY OF THE HISTORIC ENVIRONMENT}

Historically, most buildings and places of the World Heritage Sites, protected areas and landscapes (historic/registered-naturalparks and gardens) were not designed to be readily to be accessible for people with disabilities. However, today's common design approaches Universal Design-UD (Ostroff, 2011), Inclusive Design-ID (Clarkson, Coleman, Hosking, \& Waller, 2007; Coleman, 1994) and Design for All-DfA (Europe, 2004; Grosbois, 2001)used in the USA, UK and Europe respectively, are almost synonyms sharing the same objectives. Despite the fact that each term is region specific, all have the same purpose: more inclusivity. While differences exist in how these approaches have evolved, the similarities are more apparent (Ostroff, 2011). Among these design approaches accessibility is a considerable challenge. It involves rethinking the design of not only the buildings but also built environment (urban spaces, public transportation systems, urban landscapes, parks, interior spaces and sacred places). It needs also not only people with disabilities but for all (Heitzman, 2005).

Change is a reinterpretation of the continuity of cultural identity. Each value passed from the past according to the requirements of the time includes the update (Çakmak, 2013). When changes, attachments, deteriorations are accepted as a definite principle of life, changing process of processes and conditions of structures emerges as one of the indispensable parameters of theoretical thinking. Except for very symbolic monuments, because of their intrinsic cultural heritage value and their uses as places where people's daily life activities, historic environments need to be modified to meet the changing needs of their occupants. Especially, historic environments have many difficulties 
(functional, structural, accessible, usable etc.) for people with disabilities. The survival of most historic buildings depends upon their continued, viable use and this may, among other things, require alteration or little physical intervention to improve access. No theory can deny this historic property of architecture, and be satisfied with the ideal intervention fictions based on the original design and function of the building (Kuban, 2000). Thus, these interventions both meet the requirements of everyday life for the structure used actively and provide it to survive by using them. Therefore universal design, or access for all, is an overriding objective that should always be aimed for when upgrading a heritage place, but there are also cases where this is not achieved (Gökaltın, 2014).

From the smallest to the most comprehensive ones, the discussion on whether these integrated interventions done for the purpose of the design are the requirements of daily life or not, does not affect the structures' usability borders in terms of comfort conditions. Therefore, it is needed both to improve the availability of historical environments and to protect them as in an integrated way for anyone visiting or accessing them. However, it is not possible to talk about the approaches of designs that put people to the centre of the design. In this regard, that the ongoing design concept has always been shaped by the needs of the average user groups is not an exaggeration. It is nothing but only an optimism that standard design shaped according to average user groups is an inclusive approach, in other word to say that it is for all.

Man-made monuments and sites very often originated at a time when universal design was a completely foreign idea. For all that, today many buildings of architectural heritage also play an important role in people's daily life. Mosques, among the other public buildings, have a special place in the built environment in terms of public accessibility and usability. Because a mosque regularly used at least five times a day for praying should be accessible for all. Eskişehir Odunpazarı Hacı Hasan Mosque is one of the distinguished accessible mosque in Turkey after the restoration (Tutal, 2012). The process of restoration based on accessibility for all, made the mosque even more remarkable. The conversion process of Hacı Hasan Mosque which experience these deteriorations and serving as an "accessible mosque", and in the settlement pattern and coming to the fore with its features close to civil architecture. 


\section{ACCESSIBILITY OF THE HACI HASAN MOSQUE}

The mosque is located at Eskisehir Odunpazarı Urban Conservation Area, Karapınar Quarter, Hacı Hasan Street (Figure 1-2). Although the exact date of construction of the mosque is unknown. It dates back to the thirteenth century. Although blast from the plaster during restoration of the building confirms that it was converted into a mosque, the mosque as it stands today, with its typological features compared to a religious architecture, is more akin to residential properties civil architecture (Cerasi, 1999).

Figure 1-2. Odunpazarı Urban Conservation Area and Hacı Hasan Mosque.
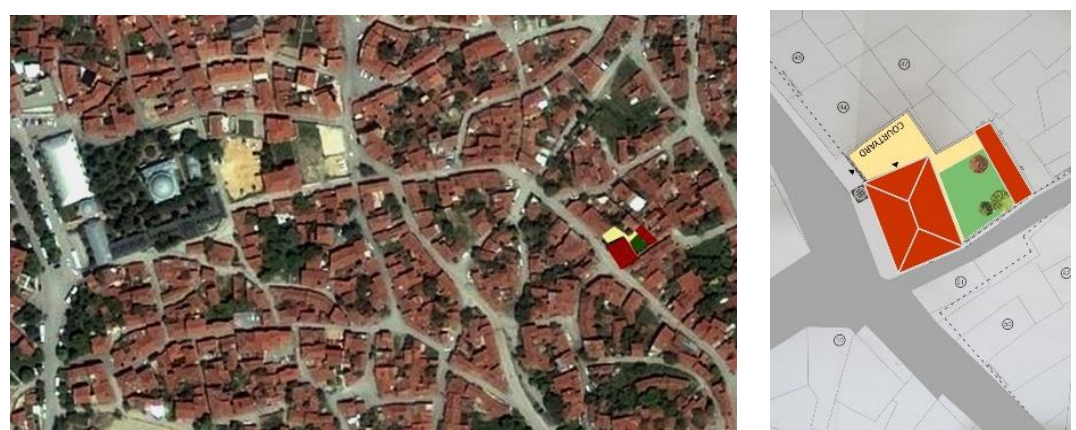

The mosque is rectangular in the direction from the gate to the altar. Place of main worship is close to a square, is separated from the entrance by the wooden studs carrying Mahfil (space for the women) at the top. While to the left of the entrance is a wooden staircase, to the right of it is a door which is for entering its minaret. The main prayer hall has a swallow ceiling with the squares in squares. The mosque is lighted with one small window located on each side of entrance door of the basement, and on the Mahfil with two small windows located in the eastern and western pockets, and two windows on the top of the entrance windows. Apart from the windows lightening the entrance to the mosque, and woman section, the mosque is also lit by two large windows located in the western and eastern fronts, and two small windows located over the altar. Windows are rectangular and arched ones. The pulpit whose two side panels are decorated with geometric paneling is just right of the altar which is in form of a niche.

Although the body walls of the mosque are made of stone materials, minaret and the arches of windows are made of brick. The body walls were ended with the application of hedgehog eaves made of bricks walls. The roof is covered with tiles. Located in the north-western corner of the building is the brick minaret in cylinder shape rests on a square base made up of cut stones. Bottom of the balcony of the one balcony mosque is adorned with rows of saw tooth-shaped bricks. The mosque which was repaired by a local association in 1950, has also received small and large 
Universal Access in Historic Environment and Accessibility of The Hacı Hasan Mosque in Eskisehir

renovations since then. The mosque was restored in 2011 by the Municipality of Odunpazarl.

There used to be a small courtyard of the mosque before the restoration, people used enter to the yard through a courtyard gate (Figure 3-4). Imam's house is used to reach by climbing a stairs adjacent to the wall of a mosque in the courtyard. Mosque entrance is located under the stairs. Hence, the mosque's entrance was closed by the house of the imam which was an attachment and its height of the roof was higher than the structure, and eastern façade of the structure was also closed by other attachments. The minaret of the mosque whose facade was plastered over the time, and moved away from the original character, and base section was of the mosaic, the body of the minaret was covered with ceramic tiles.
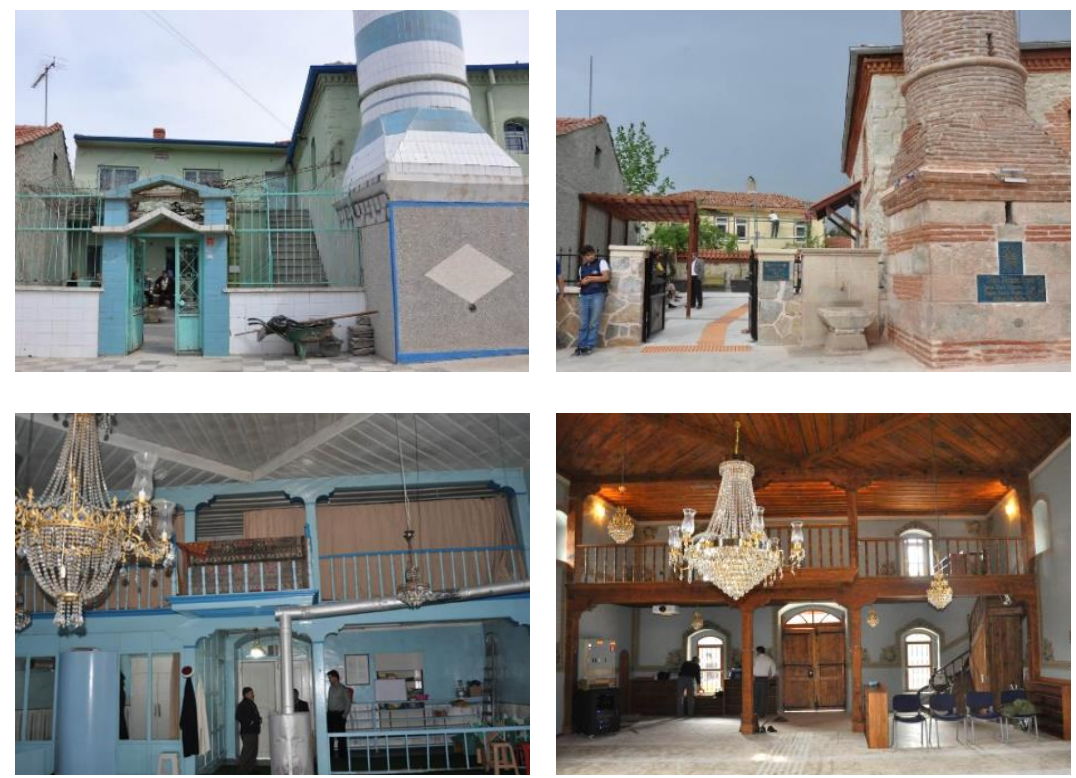

Facades except for the western one was uncovered form the existing attachments during the restoration, in accordance with the documents. Rasps made on the exterior facades revealed that building has under the plastered surface alternating (stone-brick) wall system, and the minaret which was tile covered has walls built of bricks in different colors. In the rasp of the interior made by chemical and mechanical methods, stenciled marks were found on the wall surfaces. After overlying oil painting surfaces, paste, and water-based paint layers were cleaned from the surface decoration all elements of the motif ornament decoration with the effects of westernization from 19th and end of 20th century were unearthed both in color and composition. By the wooden pole painted with oil paint, ceiling with beams and floor elements, surface cleaning for the protection and repair, and retouching and putting protective cover on complementation, it has been the original (Figure 5-6). Structural cracks seen in original plaster
Figure 3-4. Hacl Hasan Mosque, before and after the restoration.

Figure 5-6. Interior space of the Hacı Hasan Mosque, before and after the restoration. 
have been reinforced. And the exterior façades have been original pattern of stone and brick walls by extracting of the plasters and tile covers form the original surfaces. All materials which were subsequently added to the original facades cleaned, maintained and complements for necessary portions to the surface protective applications have been performed (Alabay \& Guzel, 2011).

During the restoration, studies on the mosque's accessibility were initiated and accessibility projects were prepared in accordance with standards. Instead of widely accepted accessibility which was reduced to ramps, elevators, toilets for the disabled, decisions taken on what can be done according to disability levels were discussed separately, and integrated into the restoration project. In the design process, except for standard applications, the design concept for the average user groups was rejected and the principle of "universal design" has been adopted. In the process which was distinguished with the accessibility solutions applied for a historical structure, the mosque has distinguished itself in numerous examples in the name of accessibility. In the process of restoration, the studies related to accessibility of the mosque were conducted in three categories.

\section{Accessibility for the Hearing Impaired}

Three different arrangements consisting of the Induction loop (IR) System, Sign Language and Written Information, Warning Lights for Ezan were made in terms of accessibility for the Hearing Impaired (Dorken, 2012). Induction Loop (IR) System, in simple sense, It works by the waves of magnetic induction. The audio source is connected to an IR amplifier, the amplifier by turning the signal into low-voltage electrical current, convert waves in to the magnetic induction waves through the cables laid the space. While these waves are browsing through the space, 'telecoil' in the hearing receives them, and converted into sound by the hearing aid amplifier again. The signal in this way, without any impairment in the mosque reaches from the speakers to the listeners. In practice process, two important points in the case of Hacı Hasan Mosque are noted differently from the other places in which the system is applied;

1. First, the cabling was made perimeter based because when the users' head to put on cables which were laid based on large rooms or purpose of usage during the prostrate position, they may hear a very loud noise and interference,

2. Because the users must hear the sounds both in vertical, horizontal positions an upright position wiring was made in order for the users hear the sound both in bowing and prostration positions. Cables laid not only on the floor but also on the walls for 
Universal Access in Historic Environment and Accessibility of The Hacı Hasan Mosque in Eskisehir

the sound to be heard for the hearing impaired without interruption.

Written information and sign language is reflecting the sermon preached to a big screen using a projector system and discussing the issue by the muezzin who is a sign language translator. The hearing impaired participates in worship using these two communication ways (Figure 7). Projection system is used to listening to prayer and Friday sermon. It is also used in order for the hearing impaired to learn the Quran.
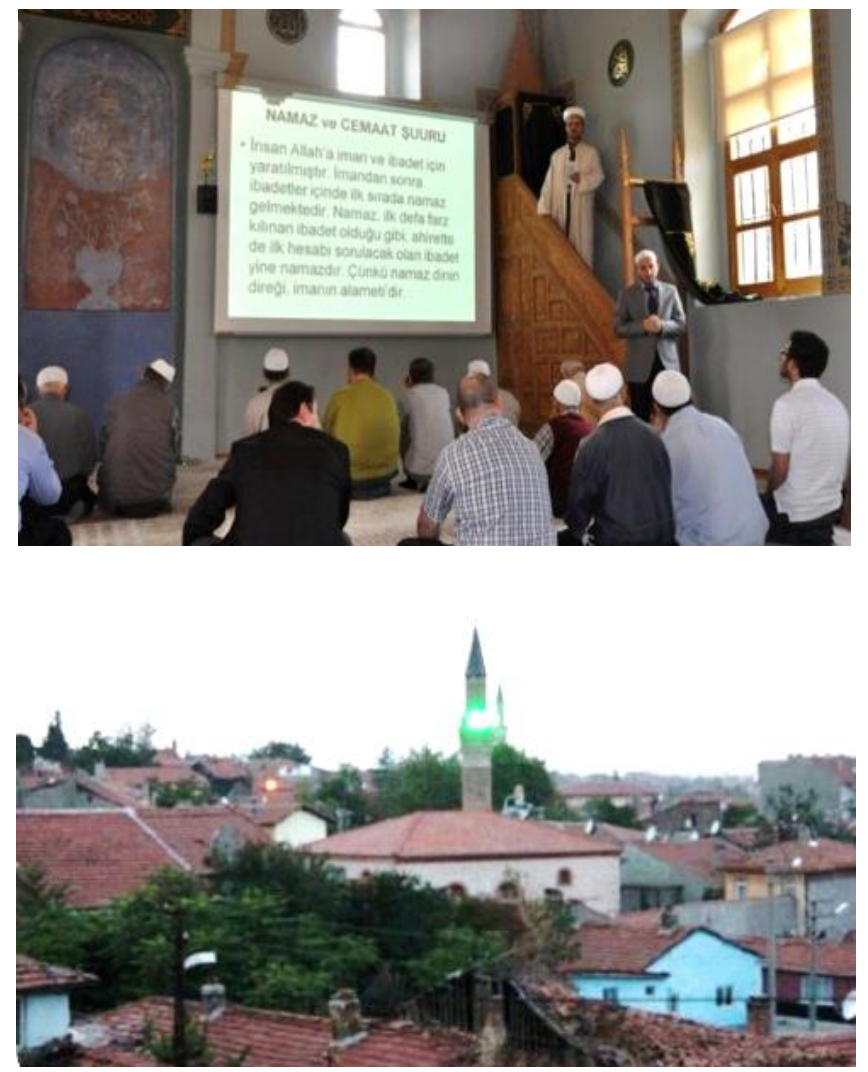

Ezan warning lights, are located on the minaret balcony and flash in order for those who don't hear call for prayer during the call to prayer (Figure 8). Because RGB light system reflects to the best during the daylight according to the level of emissions, green warning lights are selected and LED lighting system is applied.

\section{Accessibility for the Visually Impaired}

For the mosque to be used for both those who are visually impaired sensible walking surfaces have been arranged. Surface materials have contrasting colors in order for people with low vision to see the floor. Sensible walking surface materials were laid from on the sidewalk in front of the mosque to the paths in the courtyard and entrance of the mosque and other facilities (fountains, toilets, etc.) and they were made accessible to the visually impaired (Figure 9). The connection from the sidewalk to
Figure 7. The written and sign language information in the mosque.

Figure 8. RGB light system for Ezan warning. 
Figure 9-10. Tactile surface for visually impaired in the courtyard and interior space of the mosque. the interior of the mosque were leveled and the connection was arranged as no hindrance path for both visually impaired and for the orthopedically. The carpets laid on the floor of interior of the mosque were so woven so that they can be sensed by the soles of the feet in order for the visually impaired to perceive the lines (Figure 10). Braille Quran set given by Mufti of Eskisehir has large letter characters of both Turkish translation, Original Arabic. Quran and other publications are available including basic religious information. However, the mosque was purchased used in voice transmissions.
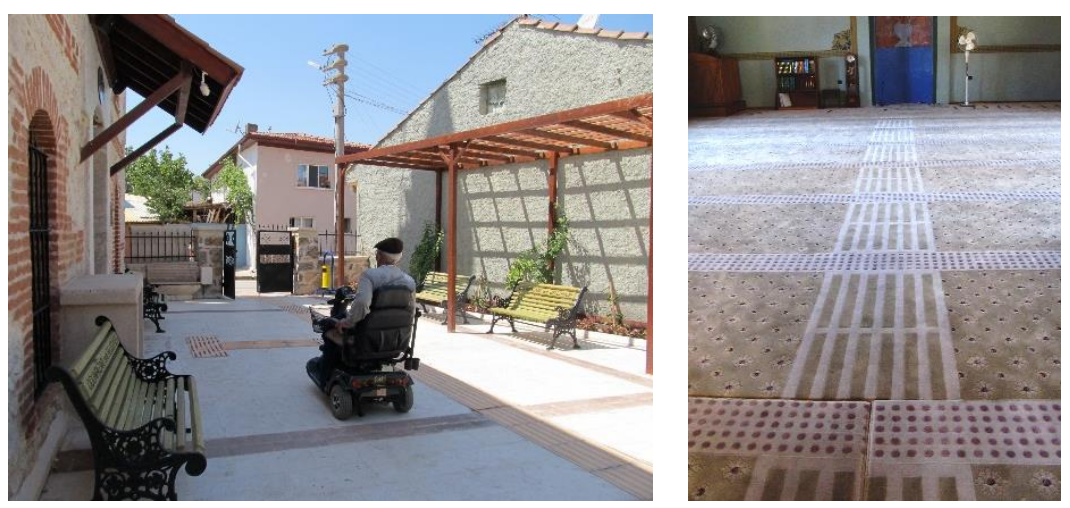

\section{Accessibility for the Orthopedically Handicapped}

During the restoration, differences in all of the internal and external spaces were leveled and a walking surface was created on both exterior and interior surfaces without barriers. While the outdoor sidewalks were made as accessible, in both mosque entrance and other facilities such as courtyard of the mosque, nursing room for mothers, toilets for the disabled, and baby care rooms were arranged to be accessible. Vertical accessibility of the first floor was provided by means of stair lift. To the interior of the mosque is provided. The wheelchair users who are among the existing prayers may both go into the mosque and whisper their prayers on them (Figure 11-12). In the side courtyard which is in the entrance area, a toilet for the people with disabilities and ablution room for the women and a nursing room they may use were built. 
Universal Access in Historic Environment and Accessibility of The Hacı Hasan Mosque in Eskisehir
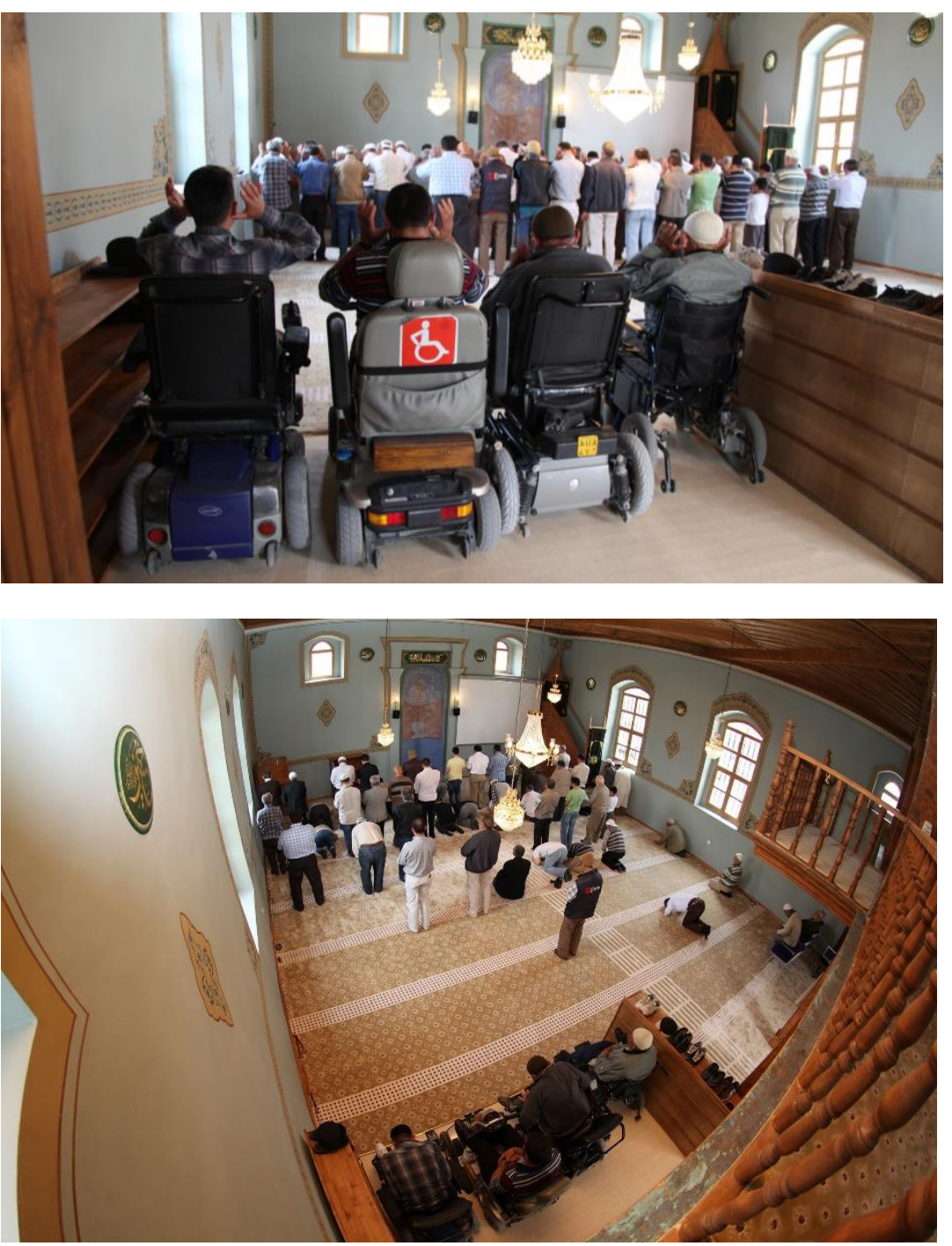

Consequently, like Hacı Hasan Mosque, each historic building or place is unique, irreplaceable resource which reflects a rich and diverse expression of past societies and the level of accessibility that can be achieved is dependent on the characteristics of the site itself (Figure 13-14). Universal access is an innovative and dynamic strategy which focuses on constantly seeking better solutions in a context where technology, knowledge and awareness such as universal design/design approach for al are rapidly changing. Thus it is necessary continually to consider new solutions as a means of minimizing technical and environmental limitations.

Improving the universal access strategy in and around the historic environment should aim to include the following goals wherever practicable:

- Comprehensive previsit information about access available in accessible formats (written, visual and audio) and providing
Figure 11. A place of worship for wheelchair users in the mosque.

Figure 12. Wheelchair users in the mosque. 
information about the accessibility level of the building, site and services,

- Accessible transportation to historic environment (accessible transportation vehicle, building and services),

- Accessible car parking as close as is reasonable,

- An accessible open spaces, landscapes, garden and routes,

- Simple and intuitive wayfinding and orientation (well designed and legible signage),

- An accessible principal entry (This is usually referred to as the principle public entrance, and may or may not be the original or historic entry)

- Staff trained in disability and equality awareness,

- Access to, and between all levels of the building and site (usability and visitability of the space)

- Programme, services (services such as telephones, vending machines, counters and retail outlets), toilets, activities and events that are accessible for all,

- Interpretive information available in a variety of formats,

- Emergency evacuation for everyone.

Figure 13-14. Hacı Hasan Mosque before and after restoration.

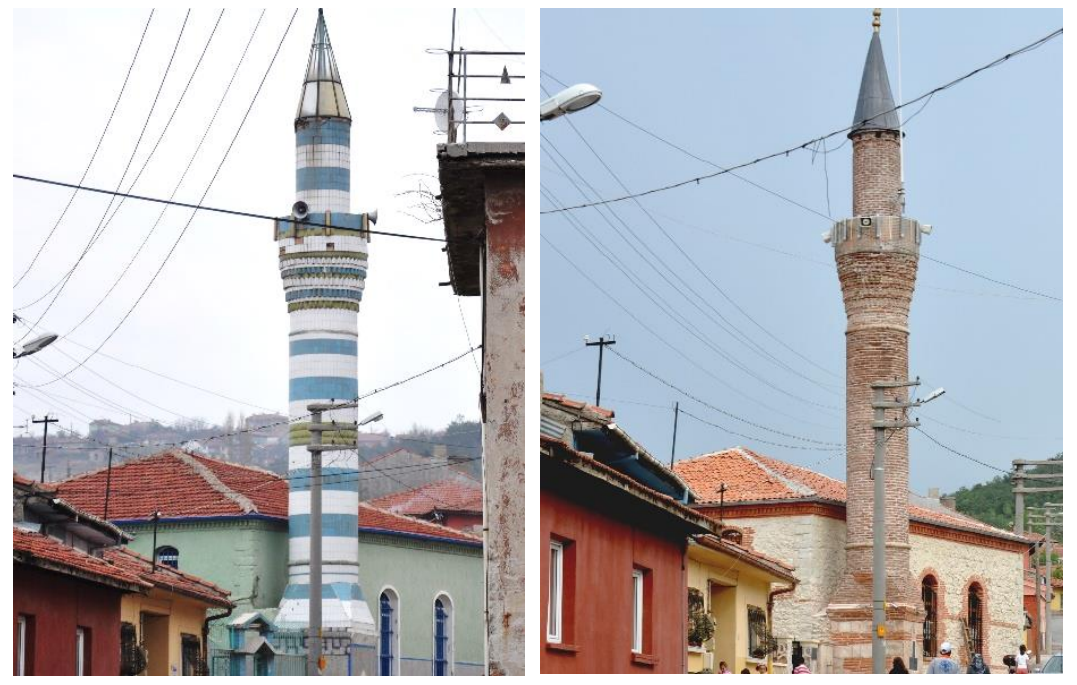

\section{CONCLUSION}

All of the technical and architectural interventions for prolonging the life of a structure with artistic value are activities of restoration. While in the context of modern restoration techniques, restoration has a scientific dimension; in terms of sensitivity to the environment it has a universal human nature dimension. When in a contemporary restoration, it is taken into account that intervention is done for extending the life of work of art and maintaining its existence. It is mandatory that the universal dimensions are only provided with universal designs or "design for all" approach. 
Worship would exist in the venues as long as people can do it. When accessibility and availability of the venue is provided for all, it can be said that the functionality of the historic environments materializes. Thus, the difference between the design which is made for the average people and the design for all arises. There is no doubt that this difference includes more accessibility than the accessibility measures which are widely misunderstood and reduced to elevators, ramps, and toilets. These measures at Odunpazarı Hacı Hasan Mosque are inclusively qualified. We wish the same for the all historic environments.

\section{REFERENCES}

Alabay, S., \& Guzel, A. (2011). Hacı Hasan Camii Raspa Sonrası Açığa Çıkan Kalem İşlerinin Restorasyon ve Konservasyon Raporu. Retrieved from Eskişehir:

All, D. F. (2008). Design For All, Disability \& Development, Social Protection \& Labor, Human Development Network Social Development Department \& Urban Development, Sustainable Development Network The World Bank.

Aslaksen, F., Bergh, S., Bringa, O. R., \& Heggem, E. K. (1997). Universal design: Planning and design for all. Retrieved from https://digitalcommons.ilr.cornell.edu/gladnetcolle ct/327/

Balaram, S. (2001). Universal design and the majority world. Universal Design Handbook, McGraw-Hill, New York, USA.

Cerasi, M. (1999). Osmanlı Kenti. İstanbul: YKY.

Clarkson, P., Coleman, R., Hosking, I., \& Waller, S. (2007). Inclusive design toolkit: Engineering Design Centre, University of Cambridge, UK.

Coleman, R. (1994). The Case for inclusive design-an overview. Paper presented at the Proceedings of the 12th Triennial Congress, International Ergonomics Association and the Human Factors Association, Canada.

Çakmak, B. Y. (2013). Kültürel Mirasın Korunması Bağlamında Bir Yeniden Kullanım Örneği, Hamdi Gültepe Evi. Artium, 1(1), 54-64.

Dorken, M. (2012). Hacı Hasan Ağa Camii İndüksiyon Döngü (ID) Sistemi Raporu. Retrieved from Eskişehir:

Europe, E. D. f. A. (2004). Stockholm Declaration Retrieved from http://www.designforalleurope.org/Design-forAll/EIDD-Documents/Stockholm-Declaration

Gökaltın, E. (2014). Eskişehir Tarihi Odunpazarı Evleri Bağlamında Dönüşüm ve Sürdürülebilirlik. Paper presented at the 1 . Uluslararası Sanat ve Tasarım Kongresi, İzmir.

Grosbois, L.-P. (2001). The evolution of design for all in public buildings and transportation in France. PREISER, Wolfgang FE \& OSTROFF, Elaine. Universal Design Handbook. Nova Iorque/EUA: McGraw-Hill.

Güler, G. A., \& Tutal, O. (2017). Tarihi Yapılarda Erişilebilirlik ve Kullanılabilirlik. Paper presented at the Uluslararası 
Katılımlı 6. Tarihi Yapıların Korunması ve Güçlendirilmesi Sempozyumu, Trabzon.

Heitzman, F. E. (2005). Universal Access in Historic Buildings, AIA, ASID. $\quad$ Retrieved from http://academics.triton.edu/faculty/fheitzman/ihpabroc hure.html

Herssens, J. (2013). Design(ing) for more - towards a global design approach and local methods Retrieved from https://www.researchgate.net/publication/268686968_ Designing_for_more_towards_a_global_design_approach_ and_local_methods

Kuban, D. (2000). Tarihi çevre korumanın mimarlık boyutu: kuram ve uygulama: Yapı-Endüstri Merkezi Yayınları.

Mace, R. (1985). Barrier Free Environments for Everyone/. Designers West(33), 147-152.

Mace, R. (2013). What is Universal Design, The RL Mace Universal Design Institute. Retrieved from http://udinstitute.org/whatisud.php

Manley, S. (2011). Taking Action to Achieve Inclusive Design, Development of the Design for all Curriculum, Design For All Workshop Final Report. Retrieved from Eskișehir:

Ostroff, E. (2011). Universal design: an evolving paradigm. In W. F. E. Presier (Ed.), Universal design handbook (Vol. 2, pp. 34-42). Newyork.

Preiser, W. F., \& Ostroff, E. (2001). Universal design handbook: McGraw Hill Professional.

Sawyer, A. (2015). Easy Access to Historic Buildings, Conservation principles. Retrieved from www.english-heritage.org.uk

Steinfeld, E., \& Tauke, B. (2002). 2.1 Universal Designing. 17 Ways of Thinking and Teaching, 165.

Story, M. F. (2001). Principles of universal design. Universal design handbook.

Tutal, 0. (2012). Dini Yapıların Ulaşılabilirliği ve Ulaşılabilir Bir Cami Olarak Eskişehir Hacı Hasan Cami. Paper presented at the I. Ulusal Cami Mimarisi Sempozyumu: "Gelenekten Geleceğe Cami Mimarisinde Çağdaş Tasarım ve Teknolojiler", İstanbul.

URL-1.

Retrieved from https://www.un.org/disabilities/documents/convention /convoptprot-e.pdf

URL-2.

Retrieved from

https://projects.ncsu.edu/design/cud/about_ud/udprinc iples.htm

\section{Resume}

Assoc. Prof. Dr. Osman Tutal is currently working at Anadolu University, Faculty of Architecture and Design, Department of Architecture. His researches mainly focus on accessibility for all, universal design/design for all, urban design. 